\title{
Policy Networks and the Roles of Public Administrations
}

Frédéric Varone, Karin Ingold, and Manuel Fischer

\subsection{INTRODUCTION}

This chapter applies the methodological tools of formal social network analysis (SNA) to illustrate the multiple functions currently performed by public administration(s) in steering public policy. Public policy itself is defined as 'a series of intentionally coherent decisions or activities taken or carried out by different public - and sometimes-private actors, whose resources, institutional links and interests vary, with a view to resolving in a targeted manner a problem that is politically defined as collective in nature' (Knoepfel et al. 2011: 24). From this perspective, a public administration is a public actor that must unconditionally coordinate its own actions with

F. Varone $(\triangle)$

Department of Political Science and International Relations, University of Geneva, Geneva, Switzerland

e-mail: frederic.varone@unige.ch

K. Ingold

Institute of Political Science, University of Bern, Bern, Switzerland e-mail: karin.ingold@ipw.unibe.ch

M. Fischer

Department Environmental Social Sciences, Eawag, Dübendorf, Switzerland e-mail: manuel.fischer@eawag.ch

(C) The Author(s) 2019

A. Ladner et al. (eds.), Swiss Public Administration, Governance and Public Management, https://doi.org/10.1007/978-3-319-92381-9_20 
those of parliamentary and governmental officials, courts, interest groups, political parties and scientific experts in order to co-produce a policy for a sector or to resolve a collective problem. In fact, in current political systems, no actor alone (including a politico-administrative actor) controls all the resources needed to take unilateral action (Berardo and Scholz 2010).

The empirical examples discussed in this chapter illustrate how classical public administration (e.g., those following the Weberian ideal type of bureaucracy) has changed and takes on new roles nowadays. On the one hand, in the process of making decisions, an administration at times becomes a policy broker between advocacy coalitions. On the other hand, during the implementation phase, it often agrees to share its regulatory powers with other actors such as independent agencies. Empirical evidence tends to confirm the paradox that it is precisely by renouncing its classical role as the dominant actor in the hierarchy, and by sharing its competences and resources with other actors, that the administration is able to maintain its central role in steering public policy. This thesis is underscored in the literature on the meta-governance of networks or network management (e.g., Klijn 2005; Provan and Kenis 2007; Sørensen and Torfing 2009; Klijn et al. 2010). In fact, the social network analyses presented here demonstrate that public administration remains central and influential and at the heart of policy networks - as long as it can adapt itself to the current conditions influencing public policies and can fulfill new functions (see also Fischer 2017).

SNA describes the relations between actors who jointly develop and implement a public policy; it is also a way to study why and how an administration occupies several roles in succession in carrying out public actions. Different labels have been applied in the public policy and public administration literature to describe the networks among actors. The first, 'policy networks', is more in line with political negotiation theories and theories of decision-making processes. Private and public actors exchange information and other resources relevant to taking action, in order to increase their influence on the final outcome of the decision-making process (Leifeld and Schneider 2012; Knoke et al. 1996). This exchange is organized within the policy networks and is often presented as a non-hierarchical approach to public sector decision-making (Kenis and Schneider 1991; Laumann and Knoke 1987). It highlights the horizontal relationships between different actors where no clear hierarchy between them exists, and it focuses on the influence administrative units exert in formulating public policies.

The second, 'collaborative networks', is derived more from the public management literature and focuses on the implementation of public policies. 
It tries to explain the quality and efficiency of services provided by a public administration, often at the local or regional level (Shrestha 2013; Schalk et al. 2010; Provan and Kenis 2007). Linked to the theoretical discourse about network governance and collaborative governance (Ansell and Gash 2007), this approach emphasizes the self-organizing, non-hierarchical character of actors involved in policy implementation and the resolution of local collective action problems or natural resource management (Lubell et al. 2014). These two currents are perfectly complementary (Lecy et al. 2014) and make it possible to recognize, if not understand, the different facets of administrative work during the different stages of the public policy cycle. This chapter focuses on the policy formulation and policy implementation stages (for a discussion of 'upstream' agenda-setting and 'downstream' policy evaluation, see Varone et al. 2016).

The 'formulation' stage corresponds to the clarification and stabilization phases (at least temporarily) in the logic of intervention which underpins public policy. This process, which leads to adopting a legislative and regulatory framework, engenders specific choices of objectives, instruments (e.g., prescriptions, incentives or information), institutional arrangements and procedures to be followed to resolve the problem under consideration.

The 'implementation' stage corresponds to the application of the policy which has been legitimized, hence to the production of administrative outputs in specific situations (e.g., a building permit, a subsidy for solar panels or training in ecological farming practices). Most of the time, this phase is quite complex, because a variety of potential snares exist, including the non-execution or very selective application of certain legislative or regulatory provisions by street-level bureaucrats with discretionary powers (Lipsky 1980). The territorial differentiation inherent to federalism also creates implementation issues, whether in a decentralized country or in a multilevel governance system of the kind found at the European level.

At each of these stages of the policy cycle, the administration can assert itself, which it may do either more or less proactively; it is central in the configuration of actors and influences the content of public policy. More generally, an SNA allows one to study the activity, centrality, and influence of an actor. This analysis is precisely aimed at providing theoretical and methodological tools for determining the real scope of an administrative unit with respect to the process and content of public policy, but also for determining the scope of other actors involved in the sectoral network.

The following sections summarize, for the policy formulation and policy implementation stages, the concepts reflecting the particular roles of an administration; it also discusses empirical measurements of that roles. This is 
illustrated using case studies of policies to combat global warming as well as to liberalize the formerly government-controlled telecommunications sector. These two public policies are chosen because they have a number of interesting characteristics: strong internationalization (there are global debates both about climate and about ways to open the telecommunications sector in Europe to greater competition), a high degree of conflict (there are strong disagreements between state and private sector actors), and they are characterized by innovations with respect to the specific instruments (e.g., tradable certificates, licenses and market regulation) and actors (e.g., the creation of independent regulatory agencies) chosen. In a nutshell, global climate and telecommunications policies reflect, in an ideal-typical manner, the current changes to the framework conditions the state faces.

In these two case studies, we have recourse to some classic SNA indicators (see Table 20.1) for quantifying the structure of a network and the significance of an administrative actor within it.

Table 20.1 Key variables in SNA

\begin{tabular}{|c|c|}
\hline Variables & Definition of the empirical measurement used \\
\hline Density & $\begin{array}{l}\text { Network density corresponds to the proportion of observed ties as } \\
\text { compared to all theoretically possible ties in the network. }\end{array}$ \\
\hline $\begin{array}{l}\text { Degree } \\
\text { centrality }\end{array}$ & $\begin{array}{l}\text { Centrality assesses the relational position of a given node in the overall } \\
\text { network. Many different indicators of centrality exist. Degree centrality } \\
\text { measures the number of incoming (in-degree) and outgoing ties } \\
\text { (out-degree) of a node. }\end{array}$ \\
\hline $\begin{array}{l}\text { Betweenness } \\
\text { centrality }\end{array}$ & $\begin{array}{l}\text { Betweenness centrality is another popular measure of centrality. It takes } \\
\text { into account the degree to which a node is located on the shortest path } \\
\text { between any two other nodes in the network. Nodes with high } \\
\text { betweenness centralities are potentially important bridging actors or } \\
\text { brokers in the network. }\end{array}$ \\
\hline $\begin{array}{l}\text { Eigenvector } \\
\text { centrality }\end{array}$ & $\begin{array}{l}\text { Eigenvector centrality is based on degree centrality; it counts the number } \\
\text { of other nodes a given node is connected to. It also takes into account } \\
\text { the centrality of the nodes a given node is related to by giving more } \\
\text { weight to more central nodes. }\end{array}$ \\
\hline Clique analysis & $\begin{array}{l}\text { A clique is a set of nodes in which every node is connected to every other } \\
\text { node. It is a subset of a network with maximum internal density. }\end{array}$ \\
\hline $\begin{array}{l}\text { Core- } \\
\text { periphery }\end{array}$ & $\begin{array}{l}\text { A core-periphery structure is characterized by a set of nodes in the core } \\
\text { of the network that are strongly inter-connected and a set of nodes in the } \\
\text { periphery of the network that are weakly related to nodes of the core. } \\
\text { This represents an ideal-typical structure to which empirically observed } \\
\text { networks can be compared to. }\end{array}$ \\
\hline $\begin{array}{l}\text { Structural } \\
\text { equivalence }\end{array}$ & $\begin{array}{l}\text { Two nodes are structurally equivalent (or similar) if they have the same } \\
\text { (or a similar) relational profile to the rest of the nodes in the network. }\end{array}$ \\
\hline
\end{tabular}

See also Wassermann and Faust (1994) 


\subsection{Policy Formulation: Brokering AND THe Choice of Instruments}

The most studied aspect of public policy in political science is the design phase. Numerous theories of decision-making processes have tried to explain changes in the choice of objectives and the instruments used in public policy; these explanations cross administrative, governmental and parliamentary domains. In fact, the measures used to intervene, whose implementation is supposed to make it possible to achieve the objectives of the policy as well as contribute to resolving the collective problem, delineate the perimeter of the targeted groups. This is the point in time when public policy becomes concrete and directly tangible for all actors involved. Each private actor can then anticipate whether or not they are targeted by the measure (or instrument) and whether or not they should change their behavior. The calibration of policy instruments is therefore one of the elements which best characterize the design or formulation of a public policy. The instruments selected determine the degree of state 'interventionism', but they also determine the rights directly granted to the various targeted actors or the obligations imposed on them. They also determine the nature and quality of the expected administrative outputs (e.g., authorizations to be granted, prohibitions or penalties to be imposed, subsidies to be allocated, taxes to be levied and information campaigns to be carried out). It is therefore not surprising that the choice of instruments is fiercely contested in the political arena.

The relevant literature proposes various theoretical hypotheses about the links between the configuration of the actors on the one hand and the choice of instruments on the other. Bressers and O'Toole (1998), for example, suggest that the degree of connection between private and public policy stakeholders (e.g., the density of relationships within the political network) as well as their degree of cohesion (e.g., shared political preferences) decisively determines the type of instrument introduced. They suggest an elevated connection and a strong cohesion, resulting from a strong link between the government and the groups targeted by a public policy, which means that a wide variety of instruments can be introduced. This will tend to favor the target groups by granting subsidies and providing information. By contrast, a network with weak cohesion and connections will likely lead to a politics influenced by abstract or normative values-and a 
lack of room to maneuver in the target groups (Bressers and O'Toole 1998: 230-32).

In a quite different vein, the Advocacy Coalition Framework developed by Sabatier and Jenkins-Smith (1993) proposes that the choice of instruments results from a conflict between different coalitions of actors. Each coalition, or each group of advocates for a cause (e.g., those who favor and those who oppose the use of nuclear energy), shares the same belief and value systems and coordinates their efforts. An SNA analysis can be useful for identifying the advocacy coalitions as well as understanding the relations between them (Ingold 2011; Fischer 2014). The work done inside a coalition results in a preference for one combination of instruments over another (e.g., the public licensing and financing of nuclear power plants versus prohibiting such plants and imposing obligation on the private plants' owners to bear the dismantling costs). According to this theoretical model, different administrative units either can be members of different coalitions (competing to assert their value systems and their own instruments) or may act as intermediaries between the coalitions. In this latter case, a public administration body aims above all to reduce the level of conflict between the coalitions and mediate between them so as to identify possible compromise solutions. As they are not part of any coalition advocating a particular cause, these administrative bodies are referred to as 'policy brokers' in the literature (Sabatier and Jenkins-Smith 1993; Ingold and Varone 2012).

A specific example illustrates how such brokering works (Stovel and Shaw 2012), and beyond that, how SNA accounts for it empirically. The case in question was the political struggle over global warming measures to be taken in Switzerland between 1990 and 2010 (Ingold 2011; Ingold and Varone 2012). Following the signing of the Kyoto Protocol (adopted late in 1997 and in force as of early 2005), which set a 2012 target of reducing greenhouse gas emissions by $8 \%$ relative to 1990 values, Swiss climate change policy was articulated in passing a first $\mathrm{CO}_{2}$ emissions law in 2000. This law called on the private market to take voluntary action to reduce greenhouse gas emissions by $10 \%$ within two years. Should this prove insufficient, an incentive tax on $\mathrm{CO}_{2}$ emissions would be introduced.

This choice of instruments reflects the fact that two advocacy coalitions were bitterly opposed: one was pro-market (it included industry, transportation, the energy sector, and the right-wing parties) and only 
supported voluntary measures, while the other was pro-environment (it included environmental associations, left-wing parties and the Federal Office for the Environment) and called for an immediate introduction of the $\mathrm{CO}_{2}$ tax. In the event, voluntary measures soon showed their limitations, and the $\mathrm{CO}_{2}$ law was revised already in 2005. It seems logical to expect an automatic implementation of the $\mathrm{CO}_{2}$ incentive tax, but its revision led to a very different result. The second law combined a $\mathrm{CO}_{2}$ tax on fuel, as the pro-environment had called for in the first law, with a 'climate penny' tax levied on fuels, an instrument proposed by the promarket coalition. This unexpected solution was the result of a compromise negotiated between the two coalitions, thanks to the subtle work and brokerage of a public administration body - in this case the Swiss Federal Office of Energy (SFOE), which intervened to find an amicable solution and prevent an escalation of the conflict between the two coalitions.

In this example, network analysis is a powerful tool for identifying the SFOE as a public policy broker. It shows first that the SFOE does not belong to either of the competing advocacy coalitions. Each coalition brings together actors with a similar profile in terms of conflict structures (vis-à-vis members of the opposing coalition) and cooperation (with members of their own coalition). The SFOE's profile is quite distinct from that of the members of either (cause-driven) coalition. Second, the SFOE possesses a high 'reputational power', meaning the actors in conflict give it credence in its mediation work. No less than $83 \%$ of the stakeholder actors declared the SFOE to be a very influential player in the decision-making process. Third-and this empirical observation is critical here-network analysis showed the SFOE to be often found at the interface between the actors who belonged to the pro-environment versus those who belonged to the pro-market coalition. In other words, the actors in conflict only collaborated indirectly and through the intermediary SFOE. This is indicated by the 'betweenness centrality' indicator, which measures the frequency with which the SFOE is found on the geodesic path between two actors who are otherwise not connected. By way of summary, Fig. 20.1 shows the morphology of the collaborative network in Swiss climate policy; the SFOE (the large gray node at the center) maintained collaborative relationships with a multitude of actors from the two camps. 


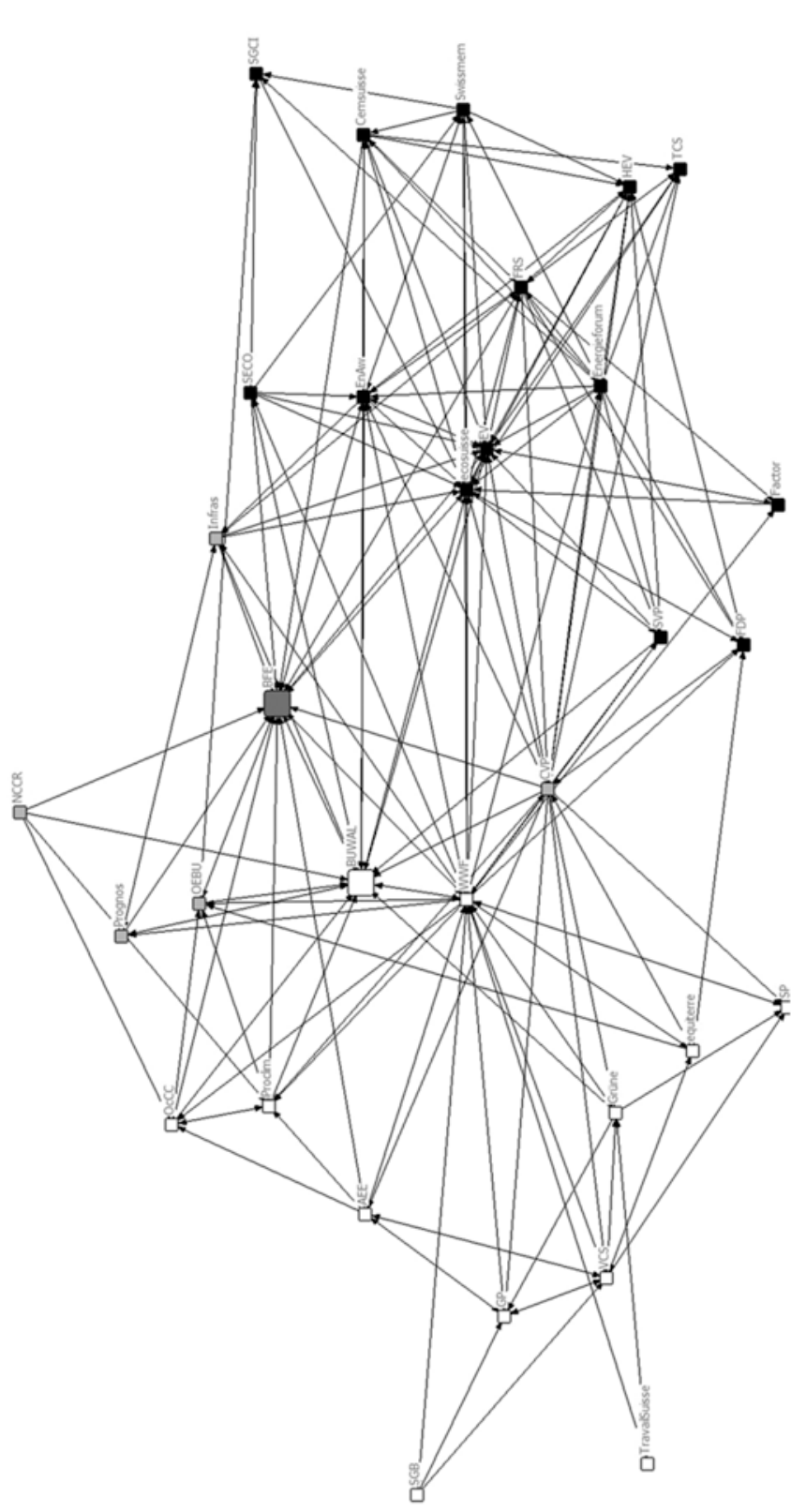

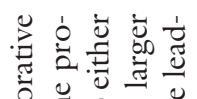

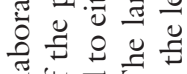
岸 ช

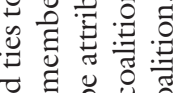
ป

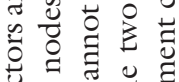
氜 艺

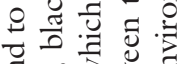
ठิ)

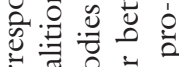
ช

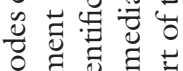
Z芯氙 iि.

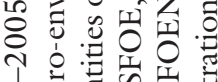

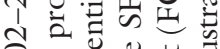

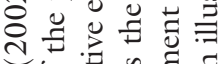

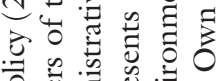

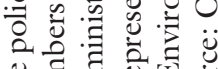

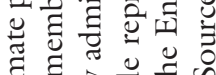

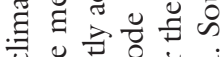

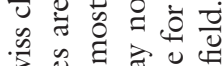

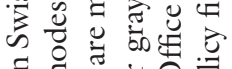

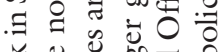

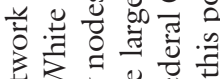

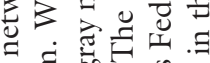

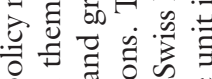
ฉ. ษั 1 ¿.

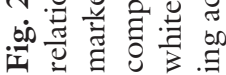




\subsection{Policy Implementation: Encouraging a Network and Co-producing Services}

The implementation phase puts public administrations in direct contact with representatives of civil society, including, first and foremost, the groups targeted by the policy instruments. To study the interdependencies and the strategic games played by these actors, one needs to identify the institutional arrangement employed in the implementation. One can also call this the structured set of administrative and parastatal organizations formally charged with implementing the relevant public policy. It is crucial that one understands the many dimensions of this inter-organizational network, as it allows one to comprehend the ability of the public administration to implement the envisaged instruments. Or put differently, to understand its inability to overcome the resistance of the target groups or the problems in application it encounters.

An implementation arrangement involves diverse administrative entities whose numbers vary. Such an arrangement is characterized by a high level of coordination both horizontally (between units) and vertically (between municipal, regional, central, and international levels), but it can, on the contrary, also be characterized by considerable fragmentation. In addition, a low degree of openness to strictly political actors implies a degree of professionalism and neutrality in implementation decisions. Greater permeability, meaning more openness to interests and interference on the part of (e.g., local) politicians, can result in politicization and unpredictability in the implementation. Finally, because public policy is often carried out by administrative units which have also participated in the formulation and execution of other sectoral policies, the question of coordination between sectors (e.g., those in which the state intervenes) is a further important issue. The evidence is that of numerous inter-ministerial conflicts; they become the subjects of administrative, political or even judicial arbitration.

Without going into all the facets of an inter-organizational network, the literature is in agreement on at least one point: a public administration nowadays often shares its regulatory powers and sees itself less a monopoly player than a co-producer of administrative outputs Moreover, an administration may be limited to encouraging (or invigorating) a network composed of parastatal or private actors to whom it delegates regulatory tasks and competencies (Provan and Kenis 2007). This phenomenon is particularly evident in the wake of New Public Management (NPM)-inspired reforms which, for example, 
lead to creating independent regulatory agencies. Many studies using a network perspective indicate that the efficiency and effectiveness of an administrative arrangement for delivering public services is highly dependent on the context, available resources, and existing administrative control mechanisms (Provan and Milward 1995; Ingold and Fischer 2014).

To illustrate the significance of inter-organizational networks and to show how traditional administrative structures have to share their prerogatives (in implementation contexts), the second example focuses on the emergence of independent regulatory agencies. In the wake of opening certain public services previously regarded as state monopolies (e.g., telecommunications, electricity, postal services or railways) to competition, most industrialized democracies instituted national regulatory agencies, also called sector-specific regulators. At least in theory, these new entities enjoyed broad independence vis-à-vis elected officials, as they were called upon to impartially manage the competition between operators, both public and private, and ensure universal service provision. Such regulatory agencies were added on to existing administrative entities, densifying the implementation mechanisms introduced by policies to liberalize public service provision.

In the telecommunications sector in Switzerland, the Federal Communications Commission is the incarnation of a national regulatory agency, one which has intervened in the network of co-regulators, alongside the Federal Office of Communication (a classical public administration body), the Competition Commission, the Swiss price regulator, and the courts charged with resolving the inevitable conflicts that arise between users, operators and/or co-regulators. Figure 20.2 outlines the relationship between all the actors in the (now liberalized) sector, relations which can be studied in greater detail using network analysis tools.

A formal network analysis of the links between actors in this realm shows that the Federal Communications Commission and the Federal Office of Communication are the two main co-producers of regulations for this sector. They both have the highest 'reputational power' and are the most central in this network. The 'classical' administrative unit, the Federal Office of Communication, also has the highest level of 'betweenness centrality' among all the actors. It can therefore exercise a great deal of control over the flow of information and benefits by having bargaining power relative to the other actors (Fischer et al. 2012; Ingold et al. 2013; Varone and Ingold 2011). In addition, the Communications Commission is strongly interlinked with the Office of Communication and other regulators, 


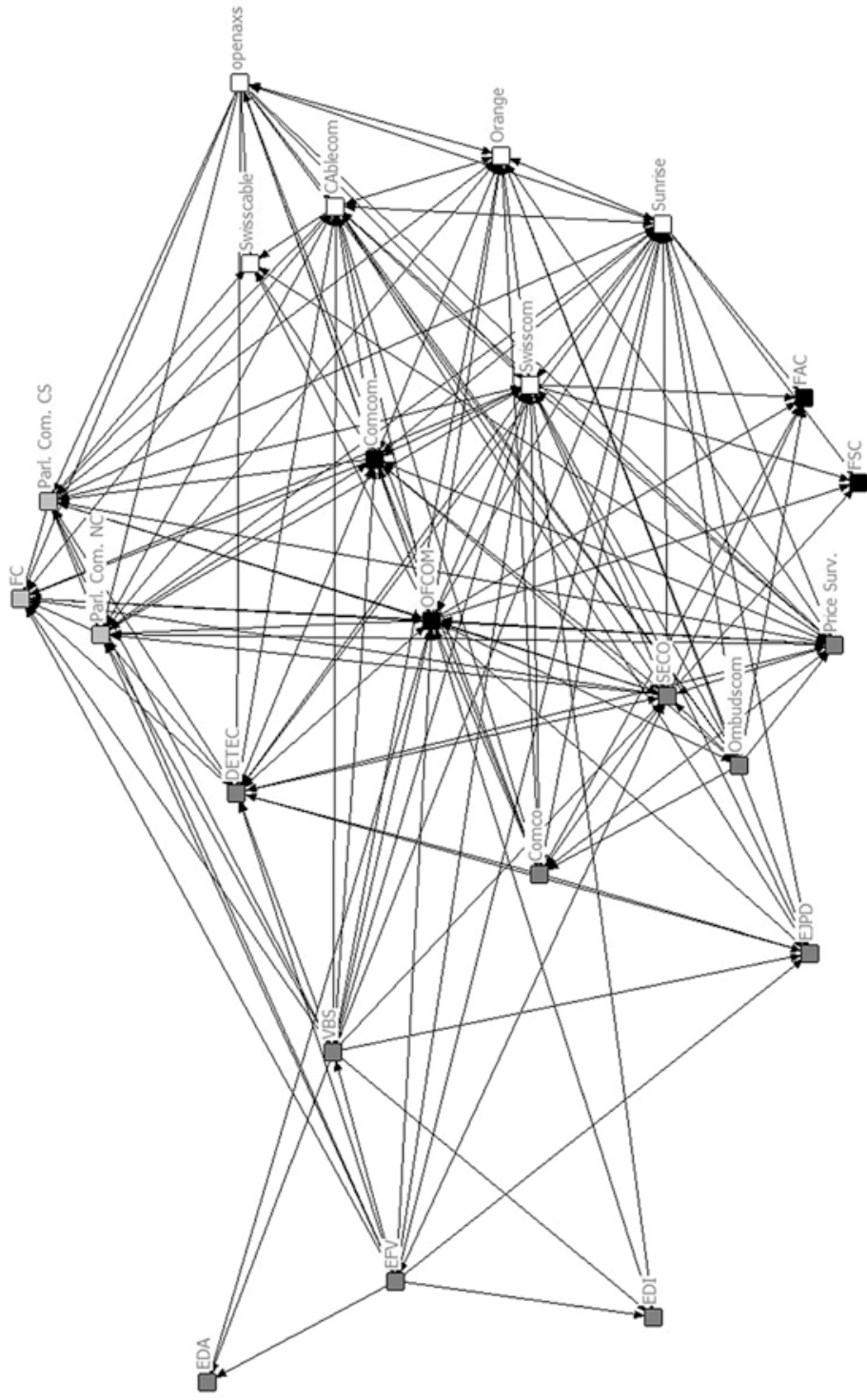

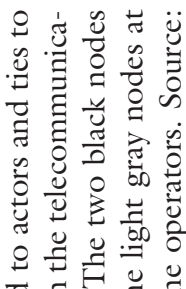

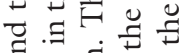

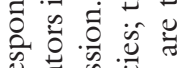

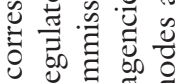

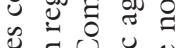

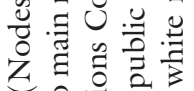

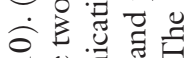

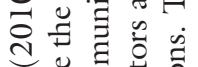

ธั。

过苛它

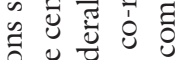

号艺记

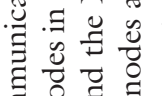

范

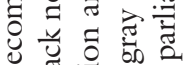

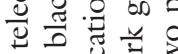

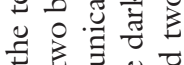

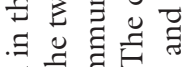

苛 0

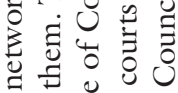

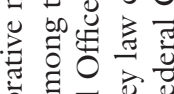

氜苛㐫

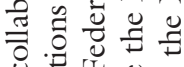

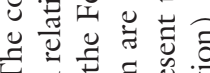

F

ㄴ.

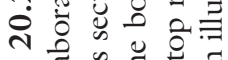

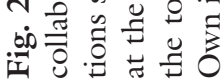


though it appears much more independent vis-à-vis the elected authorities and other operators in this sector (Maggetti et al. 2013). Thus, the sectorspecific national regulatory agency (e.g., the Communications Commission) must deal with a 'classical' administrative unit in order to exercise its regulatory powers. This example reflects the major transformation co-regulation has brought about in numerous sectors, and beyond that, the role co-production plays in the delivery of public services by 'classical' administrative bodies.

\subsection{Conclusion}

This chapter has shown how public administration(s), in order to maintain a decisive influence over the conduct of public policies, has been transformed and assumes new roles, at least when compared to the tasks and sovereign competencies under an ideal-typical Weberian bureaucracy. The two examples discussed above indicate that an administrative entity can cast itself in turn as a broker and mediator in political conflicts (formulation) and as a co-producer of administrative services and network facilitator (implementation). The results of a formal SNA also suggest that these new roles do not entail a loss of public administration influence. On the contrary: it is by adapting and also abandoning a state-centric vision and hierarchical position, as well as finding a place within a policy network as a broker, facilitator, or co-producer, that public administration is able to maintain its ability to significantly influence the content of public policies.

This observation, perhaps a little paradoxical, is certainly valid beyond the politics of contestation around global warming or the liberalizing of telecommunications. Indeed, policy networks are an undeniable reality in many sectors where the state intervenes to solve collective problems. Political decision-makers, administrative elites, and academic researchers experience this on a daily basis, and it is therefore reasonable to devote more sustained attention to the SNA approach (see Kapucu et al. 2017; Lecy et al. 2014 or Fischer 2017 for an up-to-date overview of the state of empirical research), one which helps in identifying the new roles inhabited by public administration.

Of course the emergence and consolidation of policy networks are certainly not the only transformations public administration has undergone, including in the context of NPM-inspired reforms. However, by highlighting the interdependence of public administrative units and other actors (which include private actors) in public policy, the network approach 
suggests that there are perhaps some intrinsic limitations inherent to certain other reforms which are underway, especially if they are confined to modifying the internal functioning of public administration and/or reinforcing institutional egoism. One can think here of contemporary performance contracts and performance indicators, essential tools of the NPM approach, which have been negotiated under several governments, and which generally do not take into account that public action is developed and implemented in inter-organizational networks, not in isolated administrative units which are protected by 'their' respective service contracts.

At the same time, we make no claim that policy networks are a panacea, either in theory or in practice. There is no definitive answer for whether the participation of administrative organs in policy networks improves the relevance, effectiveness and efficiency of public policies or not. While some authors highlight how public administration could profit from networkbased management (Klijn 2005), others remain cautious or even skeptical (McGuire and Agranoff 2011). A number of significant normative issues, including legitimacy, are also raised by the question of how democratically anchored policy networks are. Responsibility ultimately lies with elected decision-makers, even if delegating decision-making powers can benefit the work of public administration (Sørensen and Torfing 2005).

\section{REFERENCES}

Ansell, C., \& Gash, A. (2007). Collaborative governance in theory and practice. Journal of Public Administration Research and Theory, 18(4), 543-571.

Berardo, R., \& Scholz, J. T. (2010). Self-organizing policy networks: Risk, partner selection, and cooperation in estuaries. American Journal of Political Science, $54(3), 632-649$.

Bressers, H. T. A., \& O'Toole, L. J., Jr. (1998). The selection of policy instruments: A network-based perspective. Journal of Public Policy, 18(3), 213-239.

Fischer, M. (2014). Coalition structures and policy change in a consensus democracy. Policy Studies Journal, 42(3), 344-366.

Fischer, M. (2017). Institutions and policy networks in Europe. In J. N. Victor, M. Lubell, \& A. Montgomery (Eds.), Oxford handbook of political networks (pp. 833-854). Oxford: Oxford University Press.

Fischer, M., Ingold, K., Sciarini, P., \& Varone, F. (2012). Impacts of market liberalization on regulatory network: A longitudinal analysis of the Swiss telecommunications sector. Policy Studies Journal, 40(3), 435-457.

Ingold, K. (2011). Network structures within policy processes: Coalitions, power, and brokerage in Swiss climate policy. Policy Studies Journal, 39(3), 435-459. 
Ingold, K., \& Fischer, M. (2014). Drivers of collaboration to mitigate climate change: An illustration of Swiss climate policy over 15 years. Global Environmental Change, 24, 88-98.

Ingold, K., \& Varone, F. (2012). Treating policy brokers seriously: Evidence from the climate policy. Journal of Public Administration Research and Theory, 22(2), 319-346.

Ingold, K., Varone, F., \& Stokman, F. (2013). A social network-based approach to assess de facto independence of regulatory agencies. Journal of European Public Policy, 20(10), 1464-1481.

Kapucu, N., Hu, Q., \& Khosa, S. (2017). The state of network research in public administration. Administration \& Society, 49(8), 1087-1120.

Kenis, P., \& Schneider, V. (1991). Policy networks and policy analysis: Scrutinizing a new analytical toolbox. In B. Marin \& R. Mayntz (Eds.), Policy networks: Empirical evidence and theoretical considerations (pp. 25-59). Boulder: Westview Press.

Klijn, E. (2005). Designing and managing networks: Possibilities and limitations for network management. European Political Science, 4(3), 328-339.

Klijn, E., Steijn, B., \& Edelenbos, J. (2010). The impact of network management on outcomes in governance networks. Public Administration, 88(4), 1063-1082.

Knoepfel, P., Larrue, C., Hill, M., \& Varone, F. (2011). Public policy analysis. Bristol: The Policy Press.

Knoke, D., Pappi, F. U., Broadbent, J., \& Tsujinaka, Y. (1996). Comparing policy networks: Labor politics in the US, Germany, and Japan. Cambridge: Cambridge University Press.

Laumann, E. O., \& Knoke, D. (1987). The organizational state: Social choice in national policy domains. Madison: University of Wisconsin Press.

Lecy, J. D., Mergel, I. A., \& Schmitz, H. P. (2014). Networks in public administration: Current scholarship in review. Public Management Review, 16(5), 643-665.

Leifeld, P., \& Schneider, V. (2012). Information exchange in policy networks. American Journal of Political Science, 56(3), 731-744.

Lipsky, M. (1980). Street-level bureancracy. New York: Russel Sage.

Lubell, M., Robins, G., \& Wang, P. (2014). Network structure and institutional complexity in an ecology of water management games. Ecology and Society, $19(4), 23$.

Maggetti, M., Ingold, K., \& Varone, F. (2013). Having your cake and eating it, too: Can regulatory agencies be both independent and accountable? Swiss Political Science Review, 19(1), 1-25.

McGuire, M., \& Agranoff, R. (2011). The limitations of public management networks. Public Administration, 89(2), 265-284.

Provan, K. G., \& Kenis, P. (2007). Modes of network governance: Structure, management, and effectiveness. Journal of Public Administration Research and Theory, 18(2), 229-252. 
Provan, K. G., \& Milward, B. H. (1995). A preliminary theory of interorganizational network effectiveness: A comparative study of four community mental health systems. Administrative Science Quarterly, 40(1), 1-33.

Sabatier, P. A., \& Jenkins-Smith, H. (1993). Policy change and learning. An advocacy coalition approach. Boulder: Westview Press.

Schalk, J., Torenvlied, R., \& Allen, J. (2010). Network embeddedness and public agency performance: The strength of strong ties in Dutch higher education. Journal of Public Administration Research and Theory, 20(3), 629-653.

Shrestha, M. K. (2013). Self-organizing network capital and the success of collaborative public programs. Journal of Public Administration Research and Theory, 23(2), 307-329.

Sørensen, E., \& Torfing, J. (2005). The democratic anchorage of governance networks. Scandinavian Political Studies, 28(3), 195-218.

Sørensen, E., \& Torfing, J. (2009). Making governance networks effective and democratic through metagovernance. Public Administration, 87(2), 234-258.

Stovel, K., \& Shaw, L. (2012). Brokerage. Annual Review of Sociology, 38(1), 139-158.

Varone, F., \& Ingold, K. (2011). L'indépendance des agences nationales de régulation. In F. Bellanger \& T. Tanquerel (Eds.), Les autorités administratives indépendantes (pp. 37-61). Zurich: Schulthess Verlag.

Varone, F., Ingold, K., \& Fischer, M. (2016). Administration et réseaux d'action publique. In D. Giauque \& Y. Emery (Eds.), L'acteur et la bureaucratie (pp. 115-140). Québec: Presses de l'Université de la Laval.

Wasserman, S., \& Faust, K. (1994). Social network analysis: Methods and applications. Cambridge: Cambridge University Press.

Open Access This chapter is licensed under the terms of the Creative Commons Attribution 4.0 International License (http://creativecommons.org/licenses/ by $/ 4.0 /$ ), which permits use, sharing, adaptation, distribution and reproduction in any medium or format, as long as you give appropriate credit to the original author(s) and the source, provide a link to the Creative Commons license and indicate if changes were made.

The images or other third party material in this chapter are included in the chapter's Creative Commons license, unless indicated otherwise in a credit line to the material. If material is not included in the chapter's Creative Commons license and your intended use is not permitted by statutory regulation or exceeds the permitted use, you will need to obtain permission directly from the copyright holder.

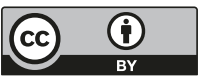

